\title{
Extracorporeal therapy for patients in deep hypothermia
}

\section{Terapia pozaustrojowa pacjentów w ciężkiej hipotermii}

\author{
Ewelina Nowak ${ }^{1,2,3}$, Edward Pietrzyk ${ }^{4}$, Agnieszka Saługa ${ }^{1,2}$, Izabela Wojarska33 , Paweł Łytek², Marianna Janion, \\ ${ }^{1}$ Department of Internal Diseases, Cardiology and Medicine Nursing, Institute of Nursing and Midwifery, Faculty of Medicine \\ and Health Sciences, Jan Kochanowski University, Kielce, Poland \\ Head of the Department: Prof. Marianna Janion MD, PhD \\ 2Department of Anesthesiology and Intensive Care Unit, Świętokrzyskie Cardiology Centre, Regional Hospital, Kielce, Poland \\ Head of the Department: Paweł Łytek MD, PhD \\ ${ }^{3}$ Doctoral Studies, Faculty of Medicine and Health Sciences, Jan Kochanowski University, Kielce, Poland \\ Head of the Faculty: Prof. Marianna Janion MD, PhD \\ ${ }^{4}$ Department of Cardiac Surgery, Świętokrzyskie Cardiology Centre, Regional Hospital, Kielce, Poland \\ Head of the Department: Edward Pietrzyk MD \\ ${ }^{5} 2^{\text {nd }}$ Department of Cardiology, Świętokrzyskie Cardiology Centre, Regional Hospital, Kielce, Poland \\ Head of the Department: Prof. Marianna Janion MD, PhD
}

Medical Studies/Studia Medyczne 2018; 34 (4): 349-352 DOI: https://doi.org/10.5114/ms.2018.80953

The discrepancy between heat production and increased heat loss leads to hypothermia. The stable body temperature kept throughout the thermoregulation ability applies only to the inside of the body, which for a healthy adult human means that the body core temperature is about $36-37^{\circ} \mathrm{C}$, is irrespective of external conditions. The lowering of the body temperature directly influences the patient's clinical condition. According to the European Resuscitation Council three types of hypothermia can be differentiated: mild hypothermia (oesophagus temperature between $35^{\circ} \mathrm{C}$ and $\left.32^{\circ} \mathrm{C}\right)$, moderate hypothermia $\left(32^{\circ} \mathrm{C}\right.$ to $\left.28^{\circ} \mathrm{C}\right)$ and deep hypothermia (below $28^{\circ} \mathrm{C}$ ). The current ERC guidelines for hypothermia include treatment with venous-arterial extracorporeal membrane oxygenation (the blood is pumped from the venous system to the arterial side) [1].

A 61-year-old male was found unconscious in the utility room and was brought by the paramedics in severe condition due to significant heat loss. During the transport to the hospital (about $12 \mathrm{~km}$ ) he suffered ventricular fibrillation that was successfully treated with defibrillation. Later he was subjected to cardiopulmonary resuscitation (CPR) with the aid of a chest compression device. He was heated with thermal blanket, and his body temperature was raised with $250 \mathrm{ml}$ intravenous infusion of $0.9 \% \mathrm{NaCl}$ to a temperature of $36^{\circ} \mathrm{C}$. Physical examination showed slowed reaction and pale, dry, cold skin, especially on the head and upper and lower limbs, normal pupil size with a slow reaction to the light, moderate level of consciousness disturbances (10 points in Glasgow Coma Scale), unmeasurable blood pressure (RR), irregular heart rate of about $50 \mathrm{bpm}$, bradypnea (10 breaths/min), and hyperglycaemia (157 mg\%). No injuries were detected. Deep hypothermia $\left(23^{\circ} \mathrm{C}\right.$ in the oesophagus) was di- agnosed, and CPR procedures were continued with the use of a chest compression device. The Medical Rescue Team contacted the Cardiac Surgery Clinic to inform about the priority patient. At 8:05 a.m. the patient was admitted to the Hospital Emergency Department where the CPR was continued. Subsequently, he was transported to the Cardiac Surgery Clinic and at 8:30 a.m. he was transported to the surgical unit for ECMO (A-V ECMO). The procedure of extracorporeal membrane oxygenation in arteriovenous vein configuration was started about $100 \mathrm{~min}$ from the SCA. At 10 a.m. the patient was sedated and subdued to mechanical ventilation. He was administered catecholamines, and his mean arterial blood pressure (MAP) was kept between 60 and $80 \mathrm{~mm} \mathrm{Hg}$. The proper body temperature $\left(36.6^{\circ} \mathrm{C}\right)$ was regained within $24 \mathrm{~h}$ of using the ECMO treatment. In the second day of the patient's hospitalisation cardiac tamponade occurred. Pericardial drainage was conducted, but due to its ineffectiveness the patient was subjected to thoracotomy, which relieved the pericardium $(300 \mathrm{ml})$, and the patient's condition stabilised. The ECMO treatment was stopped, but the patient was still sedated and mechanically ventilated, and he received catecholamines intravenously. The cause of cardiac tamponade was unknown; it was thought that the complication could be due to the mechanical compression of the chest. On the sixth day after stabilisation the tracheal tube was removed and rehabilitation was started. After 23 days of hospitalisation the patient was transferred to the Public Nursing Home in general good condition.

A 35-year-old male was found in September in a public place in generally severe condition due to significant heat loss. During the physical examination pale, dry, cold skin was observed. The patient's 
pupils were contracted and non-reactive to light, and his blood pressure was unmeasurable (RR). The patient was bradycardic (38 bpm), suffering from bradypnea (10 breaths per minute) and hyperglycaemia ( $245 \mathrm{mg} \%$ ). No injuries were detected. He was diagnosed with deep hypothermia $\left(24^{\circ} \mathrm{C}\right.$ in the oesophagus). After admission to the Hospital Emergency Department (about $4 \mathrm{~km}$ away) at 9:26 a.m. The patient suffered SCA due to ventricular fibrillation. He was successfully resuscitated (CPR), chest pressure was compressed using a chest compression device, and he was given $250 \mathrm{ml}$ of intravenous infusion of balanced electrolyte solution at the temperature of $36^{\circ} \mathrm{C}$. Nineteen minutes later he was transferred to the operating unit of the Cardiac Surgery Clinic of the Regional Hospital in Kielce, with the diagnosis of deep hypothermia, for immediate surgical implantation of an ECMO arteriovenous artery. An artery and iliac external iliac vein were made. From the time of the SCA until the A-V ECMO was started 99 min elapsed. After the surgery extracorporeal membrane oxygenation was started. During his stay in the clinic, the patient was sedated and intubated with ventilatory support. The blood circulation was stabilised with intravenous infusion of catecholamines, the acid-base homeostasis was reinstated, and the body temperature was gradually raised. Patient's RR was stabilised on the level of 100/50 $\mathrm{mm} \mathrm{Hg}$, diuresis was assisted (4000 ml/day), and he was transfused with three units of plasma. On the second day after regaining proper body temperature and stabilising the circulatory system, the ECMO was removed in surgery. The applied intensive therapy led to general condition improvement. The ECG recording showed sinus rhythm and no significant abnormalities (Figure 1). On the fourth day cardiacrespiratory stability was regained (the patient was conscious, the tracheal tube was removed, and rehabilitation was started). After 12 days of hospitalisation the patient was discharged from hospital in general good condition.

In the middle of the $20^{\text {th }}$ century hypothermia was differentiated as a separate disease entity. A central body temperature (measured in the lower $1 / 3$ part of the oesophagus, the bladder, anus, or the eardrum) lower than $35^{\circ} \mathrm{C}$ was the main diagnostic criterion. The European Resuscitation Council (ERC) also allows hypothermia diagnosis in situations where the central body temperature cannot be measured but the medical interview confirms exposition to low temperature and the patient's body is cold [2-4].

No uniform classification of hypothermia has been accepted; there are several different classifications. According to the American Heart Association (AHA), when the body temperature is as low as $34^{\circ} \mathrm{C}$ the diagnosis is mild hypothermia, with temperatures $34-30^{\circ} \mathrm{C}$ we talk about moderate hypothermia, and
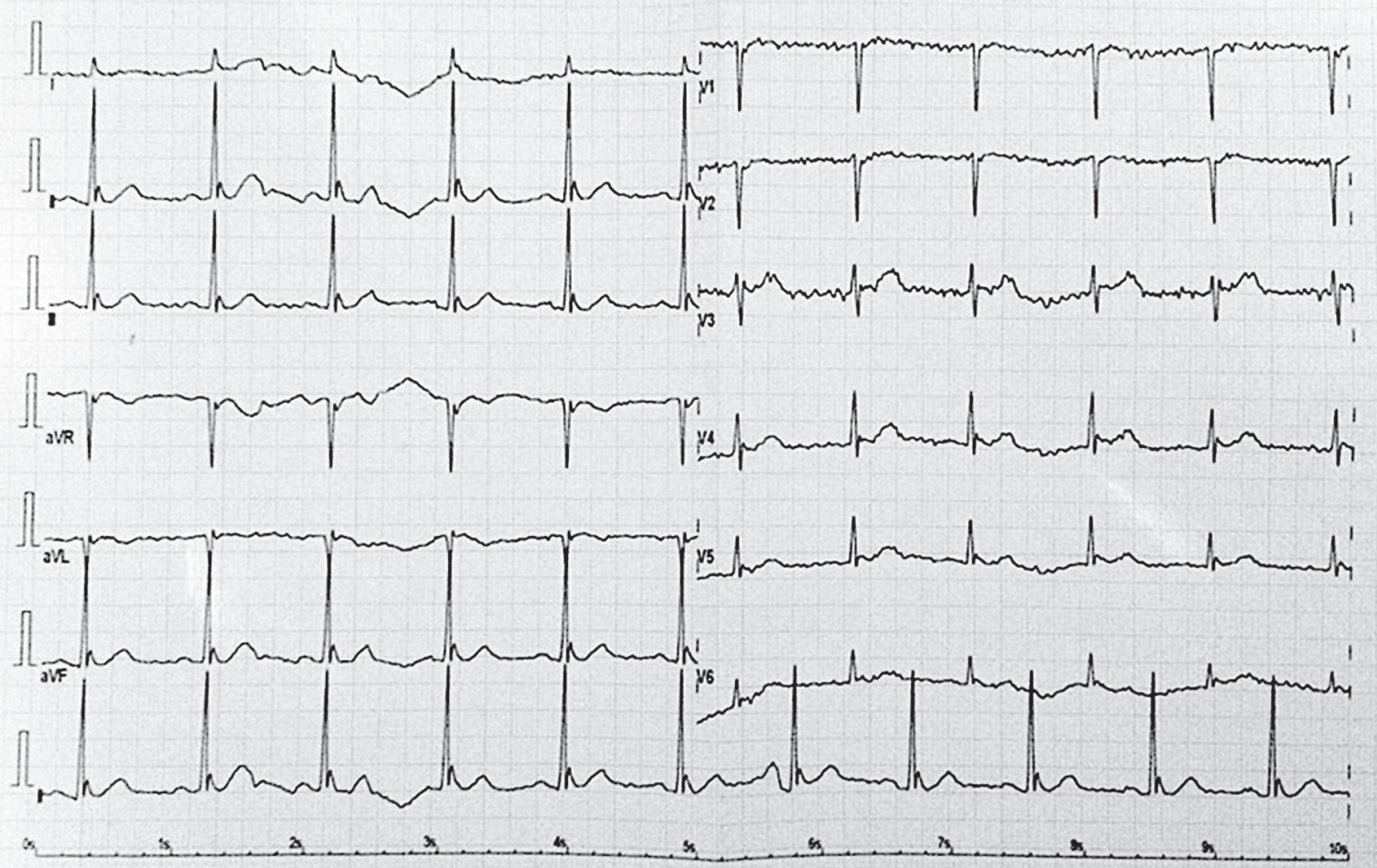

Figure 1. Sinus rhythm, no significant abnormalities 
below $30^{\circ} \mathrm{C}$ it is deep hypothermia [1]. The ERC states that mild hypothermia is diagnosed when the body temperature is between $35^{\circ} \mathrm{C}$ and $32^{\circ} \mathrm{C}$, moderate hypothermia for temperatures between $32^{\circ} \mathrm{C}$ and $28^{\circ} \mathrm{C}$, and deep hypothermia with temperatures below $28^{\circ} \mathrm{C}$ [1]. Both described cases were diagnosed with deep hypothermia based on the body temperature measurement in the oesophagus.

Lowering body temperature influences directly the patient's clinical condition. Mild hypothermia causes the onset of the body's adaptive changes like tachycardia, increased cardiac output and raised blood pressure, elongation of the PR and QT periods in the ECG recording, peripheral vasoconstriction, and arrhythmia. The respiratory system reacts with tachypnoea, increased minute volume, respiratory alkalosis, and increased oxygen intake. The patient becomes apathetic and ataxic, suffers from amnesia, dysarthria, tremor, and lowered brain metabolism. Other symptoms are polyuria, electrolyte disturbances, abnormalities in blood clotting process, increase in haematocrit level and in catecholamine secretion. Insulin secretion is decreased and the glycaemic index grows [1].

In moderate hypothermia the body's compensational mechanisms are failing, and this leads to bradycardia, lowered cardiac output, and lowered arterial blood pressure. Heart rhythm disturbances occur. The respiratory system suffers from bradypnea with decreased minute volume and low oxygen intake. Defensive mechanisms (like coughing) are absent. The patient presents with paradoxical behaviours, stupor, and hallucinations. Loss of consciousness, pupil dilation, and abnormalities in pupillary reflex may be present. Urinary tract disturbances include polyuria and electrolyte disturbances. Renal filtration decreases and the tremor stops [5].

Severe hypothermia causes bradycardia, lowered cardiac output, lowered arterial blood pressure, and arrhythmia, and with temperatures below $26^{\circ} \mathrm{C}$ it may lead to asystole. When the temperature is below $24^{\circ} \mathrm{C}$ it causes apnoea, further lowering of blood oxygenation, and pulmonary oedema. Oliguria is observed. Cerebral circulation is decreased, and the brain's electric function is lowered. In deep hypothermia reflexes are stopped and coma starts [6].

The statistical data from General Police Headquarters show that in the years 2009-2013 in Poland 853 people died from hypothermia [1]. The Information Centre of Central Statistical Office reports as many as 2198 deaths in the same period [7]. It is estimated that this number can be significantly higher because posttraumatic hypothermia and secondary hypothermia are not included in this data.

Although intuitively linked with cold weather conditions, hypothermia may develop at any time of the year. This was the case with one of the patients described in this paper. He was found in September, in a public place, in severe condition and was diagnosed with deep hypothermia based on the temperature measurement in his oesophagus $\left(24^{\circ} \mathrm{C}\right)$.

After diagnosing hypothermia, the priority in the rescue procedure is to introduce an effective method of rewarming. According to actual ERC guidelines, the best treatment for deep hypothermia is extracorporeal membrane oxygenation - ECMO [1]. The ECMO is extracorporeal blood oxygenation in which the blood is oxygenated and the carbon dioxide is removed in an oxygenator with the use of a cardiopulmonary bypass [8].

The Severe Accidental Hypothermia Centre (CLHG) formed by the Anaesthesiology and Intensive Care Department of Specialist Hospital John Paul II in Krakow developed qualification criteria for ECMO. These criteria include: evident instability of circulation, cardiac arrest during hypothermia (CPR with mechanical chest compression), deep hypothermia (temperature measured in the lower $1 / 3$ of the oesophagus, in the bladder, anus, or the eardrum is lower than $28^{\circ} \mathrm{C}$ ), and no present signs of irreversible death [3]. The presence of one of the aforementioned criteria qualifies the patient for ECMO. In both of the analysed cased the patients were admitted to the clinic in the middle of resuscitation with the diagnosis of deep hypothermia. They were immediately transferred to the operating theatre for the implantation of ECMO, which was the key factor of their survival. Both cases presented with cardiogenic shock symptoms, they required the use of catecholamines, blood and blood products, frequent blood gas control, as well as blood clotting and biochemical testing.

In both cases the treatment effects were very effective due to use of an ECMO rewarming method. The patients were discharged in good condition after few days of hospitalisation. Using VA-ECMO as a universal method for hypothermia treatment is not free from complications. The patient may suffer bleeding, cardiac tamponade, atrium perforation, infection, multiple organ failure, and metabolic disturbances $[9,10]$. Other described undesirable effects include pneumothorax, lung pulmonary oedema, kidney failure, and low cardiac output syndrome that requires the use of catecholamines [10].

One of the described patients suffered from cardiac tamponade. Pericardial drainage was ineffective. The patient was subjected to thoracotomy, which relieved the pericardium and stabilised the patient's condition

In conclusion, hypothermia may develop at any time of year. The circumstances that most often lead to hypothermia are cold air, weather conditions increasing the feeling of cold (high humidity, wind), and significant heat loss. Early diagnosis, identification of risk factors, and proper patient qualification for ECMO rewarming method enable efficient treatment. 


\section{Conflict of interest}

The authors declare no conflict of interest.

\section{References}

1. Sosnowski P, Mikrut K, Krauss H. Hipotermia - mechanizm działania i patofizjologiczne zmiany w organizmie człowieka. Postep Hig Med Dosw 2015; 69: 69-79.

2. Darocha T, Kosiński S, Jarosz A, Sobczyk D, Gałązkowski R, Sanak T, Hymczak H, Kapelak B, Drwiła R. Zasady postępowania $\mathrm{w}$ wychłodzeniu - małopolski program pozaustrojowego leczenia hipotermii. Kardiol Pol 2015, 73: 789-94.

3. Darocha T, Kosiński S, Jarosz A. Procedura pozaustrojowego leczenia pacjentów w hipotermii głębokiej. In: Hipotermia. Kliniczne aspekty wychłodzenia organizmu. Mechanizmy zagrożeń i kierunki nowoczesnego leczenia. Kosiński S, Darocha T, Sadowski J, Drwiła R (eds). Wydawnictwo Uniwersytetu Jagiellońskiego, Krakow 2016; 143-9.

4. Drwiła R. Terapia pozaustrojowa pacjentów w hipotermi głębokiej. In: Hipotermia. Kliniczne aspekty wychłodzenia organizmu. Mechanizmy zagrożeń i kierunki nowoczesnego leczenia. Kosiński S, Darocha T, Sadowski J, Drwiła R (eds). Wydawnictwo Uniwersytetu Jagiellońskiego, Krakow 2016; 117-25.

5. Zawadzki A, Jureczko R. Postępowanie ratunkowe w zagrożeniach środowiskowych. In: Medycyna Ratunkowa i Katastrof. Zawadzki A (ed.). Wydawnictwo Lekarskie PZWL, Warsaw 2011; 90-6.

6. Saxena P, Shehatha J, Boyt A. Role of extra-corporeal circulation in the management of accidental deep hypothermia. Heart Lung Circulation 2009; 18: 410-8.

7. Zgony w latach 2009-2013 na terenie Polski. Centralne Informatorium GUS, Warsaw 2015.

8. Cardiopulmonary Bypass. Ghosh S, Falter F, Cook DJ (eds). University Press, Cambridge 2009; 177-86.

9. Godula E, Szurlej D, Szurlej B. Terapia pacjentki przy użyciu pozaustrojowego natleniania krwi (ECMO) oraz jej rehabilitacja w przebiegu ostrej niewydolności oddechowej (ARDS). Fizjoter Pol 2012; 12: 397-403.

10. Truhlář A, Deakin CD, Soar J, Khalifa GE, Alfonzo A, Bierens JJ, Brattebø G, Brugger $H$, Dunning J, HunyadiAntičević S, Koster RW, Lockey DJ, Lott C, Paal P, Perkins GD, Sandroni C, Thies KC, Zideman DA, Nolan JP; Cardiac arrest in special circumstances section Collaborators. European Resuscitation Council Guidelines for Resuscitation 2015: Section 4. Cardiac arrest in special circumstances. Resuscitation 2015; 95: 148-201.

\section{Address for correspondence:}

\section{Ewelina Nowak}

Department of Internal Diseases,

Cardiology and Medicine Nursing

Institute of Nursing and Midwifery

Faculty of Medicine and Health Sciences

Jan Kochanowski University

ul. Żeromskiego 5, 25-369 Kielce, Poland

Phone: +4878 8778945

E-mail: ewelinanowakkielce@gmail.com 